\title{
The effect of overvalued equity on the relationship between audit quality and earning quality (Evidence from Iran)
}

\author{
Seyed Kazem Ebrahimie, Ali Bahraminasab, Fatemeh Khorram* \\ Department of Accounting, Semnen University, Semnan, Iran \\ *Email address: khorramfateme@yahoo.com
}

\begin{abstract}
The purpose of this article is to investigate the effect of overvalued equity on the relationship between audit quality and earning quality. In this article audit firm size, auditor industry specialization and auditor tenure were used as audit quality variable. The sample population consists of 189 companies listed in Tehran stock Exchange during the period 2008 to 2012. To test the hypotheses, OLS in Eviews has been used and investigation method of data is panel. The results show a reverse relationship between all audit quality variables and absolute discretionary accruals indicating that high audit quality causes higher earning quality. But the existence of overvalued equity cause decreasing or reversing of these relationships, in other words, when a firm is highly valued the accruals' decreasing effect of high quality auditors is reduced.
\end{abstract}

Keywords: Audit quality; Earing quality, Price earnings ratio; Highly valued equity; Discretionary accruals

\section{INTRODUCTION}

Accounting profit which provides using accrual system, from the perspective of many users of financial statements, is a tool for measuring the performance of company. On the other hand, Accounting regulations allow managers to affect financial reports by selecting accepted procedures. This policy helps manage reported earnings and better reflect firms' economic position. Selecting policies to transfer present expenses to future expenses and forthcoming revenues to present revenues have been gathered together, which makes it difficult to attain objectives in the future periods. The finance literature has widely documented that overvaluation intensifies income-increasing earning's management activities. Jensen (2005) argues, also, that when a firm becomes overvalued, i.e. the price of the firm becomes greater than its underlying economic value; managers are motivated to perpetuate overvaluation, which is consistent in principle with arguments in Renas and Cebula (2005). Although numerous reporting alternatives are available to achieve earnings management goals, accruals are an especially attractive choice since they are a normal part of the financial reporting process and their amounts require forward looking estimates over which managers have considerable discretion. Audit quality studies document that accruals decrease when the audit firm is large, or the audit firm is an industry specialist, or the auditclient tenure is long. The purpose of this paper is to posit that incentives related to highly- 
valued equity mitigate these results, as managers use income increasing accruals to augment earnings.

\section{LITERATURE AND THEORY}

\subsection{Highly valued equity}

Beginning with Jensen (2005), a significant stream of research has developed regarding the overvalued equity hypothesis. Houmes et al. (2013) suggest that when a firm is highly valued the accruals' decreasing effect of high quality auditors is reduced.

Jie Chen (2007) examines the relationship between discretionary accruals and returns from the prior year or after the year of the stock market. The results indicate that managers tend, in the face of higher abnormal returns, to support equity overvaluation through increasing earnings management. Anderson and Brooks (2006) document that the difference in returns between value and glamour firms almost doubles when $\mathrm{P} / \mathrm{Es}$ are calculated using average earnings over the last eight years. Hence, from a market value perspective and relative to other companies, the very firms that are expected to perform the best, on average, tend to perform worse. Since expectations are particularly high for highly valued firms, when managers foresee the operational inability of their firms to meet expected performance targets, incentives to manage earnings increase. An important deterrent against these incentives is the audit.

Researchers conclude that when managers face material abnormal returns, they tend to support overvalued equity through income-increasing earning management (Badertscher, 2010; Chi \& Gupta, 2009; Jie Chen, 2007; Graham et al., 2005). Higher discretionary accruals are associated with lower future abnormal stock returns, and more importantly, this association becomes stronger as prior overvaluation intensifies. Among the most overvalued firms, those with high discretionary accruals underperform those with low discretionary accruals during the following year (Chi and Gupta, 2009).

\subsection{Audit quality}

Chen et al., (2005) in their study tested the relationship between audit quality and earnings management for Taiwanese companies that offer their shares in stock for the first time. They use from proficiency of auditor in the industry and firm size as audit quality and abnormal accruals calculated using the modified Jones model as earnings management. The results showed that the Big Five audit firms will reduce earnings management. In other words, high quality of auditors limits earnings management of Taiwanese companies. Becker (1998) in their study found that there is positive and significant relationship between low audit quality and discretionary accruals. Memis and Cetenak (2012) in their study investigated the effect of audit quality on earnings management. Researchers used from the audit firm size as an indicator to measure audit quality. The results showed that there is no significant relationship between audit quality and earnings management. Test results of control variables showed that there is negative and significant relationship between firm size and return on assets with earnings management. But it was not observed positive and significant relationship between financial leverage and discretionary accruals. Zgarni (2012) in their study studied the relationship between audit quality and earnings management. The results indicate that there is significant and negative relationship between the variables of auditor proficiency in industry and auditor size with earnings management. But it was not 
observed significant relationship between auditor tenure period and earnings management. Davis et al. (2000) in their study concluded that there is negative and significant relationship between audit quality and earnings management. In addition, in a study which performed by Azibi and Rajhi (2008) and Abdul Rahman and Ali (2006), found that audit firm size has no effect on the reduction of discretionary accruals. The value of accounting information is a function of its credibility, and a central objective of audits is to enhance the quality of financial reporting. Prior studies have provided several empirical surrogates to measure audit quality. These include audit firm size, audit industry specialization, and the length of the auditor-client relationship.

Beginning with DeAngelo (1981), decades of research have shown that large audit firms with greater resources and more reputation at stake perform higher quality audits (Beatty, 1989; Houmes et al., 2012, etc). Houmes and Skantz (2010) provide evidence that the magnitude of the inverse relation between operating cash flow and accruals increases if the firm is highly valued and assert that incentives to manage earnings increase when operating cash flow is weak. Although they do not offer any direct tests relating to the effect of high valuation on audit quality after excluding loss firms, they find (not tabulated) evidence large Big N auditors reduce this tendency. Mansi et al. (2004) show that the cost of debt decreases with tenure and Carcello and Nagy (2004) document an increase in the incidence of financial reporting fraud when audit firm tenure is less than three years.

Although audit opinions enhance the credibility and reliability of financial reports, they also reflect a negotiation dimension and, within the ethical and technical confines of accounting standards, a firm's published financial report may be perceived as a joint statement from the manager and auditor (Antle and Nalebuff, 1991).

\section{METHODOLOGY}

\subsection{Participants}

Statistical population of this study includes all the listed companies in Tehran Stock Exchange. Sampling method also is systematic elimination method; therefore, companies that have the following conditions were selected for the period 2008-2012.

1. These companies are listed in Tehran Stock Exchange before the year 2008.

2. In order to increase comparability, the end of their fiscal year leads up to December 31.

3. In order to information homogeneity, companies should be manufacturing and are not investing and financing companies.

4. Their financial period has not changed during the studied period.

By applying these restrictions, 189 companies during the period 2008-2012 were selected.

\subsection{Data analysis}

The present study is application type based on the purpose to do it and is descriptivecorrelation based on the nature and method. The statistical model used in this study is a multivariate regression model. To estimate the research model panel data model is used. In this method, time series and cross-sectional data are combined with each other and are used for those problems that cannot be investigated as a time series or cross-sectional. To estimate the efficiency of a regression model using panel data, it is necessary that using appropriate tests is selected one of the common effects, fixed effects and random effects models. 
Therefore, first to select between the common effects and fixed effects models are used FLimer test. If a fixed effect model is selected, the Hausman test is performed to choose between fixed effects and random-effects models. In this study, to investigate the independence of the errors of the regression model is used Durbin-Watson test (DW) and to accept or reject the main hypothesis of the research is used the t-student statistic and also the main hypothesis is formulated as follows:

H1. The inverse relation between the discretionary accruals of the clients of large audit firms and the discretionary accruals of the clients of other audit firms changes if the clients are highly valued.

H2. The inverse relation between the discretionary accruals of the clients of industry specialist audit firms and the discretionary accruals of the clients of other audit firms changes if the clients are highly valued.

H3. The inverse relation between the discretionary accruals of audit firms' clients with long tenure and the discretionary accruals of clients with shorter tenure changes if the clients are highly valued.

H4. The inverse relation between the discretionary accruals of the clients of audit industry specialist audit firms with long tenure and the discretionary accruals of other clients changes if the clients are highly valued.

\subsection{Discretionary accruals}

Our dependent variable is discretionary accruals $\left(\mathrm{DAC}_{\mathrm{it}}\right)$. For all firms, discretionary accruals are estimated using the cross sectional version of the modified Jones model (Jones, 1991). The modified Jones model has been used in a variety of research settings (Becker et al., 1998; Francis et al., 1999; Reynolds and Francis, 2000, etc.). The model is specified as follows:

$$
\mathrm{TAC}_{\mathrm{it}} / \mathrm{TA}_{\mathrm{it}-1}=\beta_{0}+\beta_{1}\left(1 / \mathrm{TA}_{\mathrm{it}-1}\right)+\beta_{2}(\Delta \mathrm{REV}-\Delta \mathrm{AR}) / \mathrm{TA}_{\mathrm{it}-1}+\beta_{3} \mathrm{PPE}_{\mathrm{it}} / \mathrm{TA}_{\mathrm{it}-1}+\varepsilon_{\mathrm{it}}
$$

Where $\mathrm{TAC}_{\mathrm{it}}$ is the difference between firm i's year $\mathrm{t}$ earnings before extraordinary items and net cash flow from operations scaled by beginning of year $(\mathrm{t}-1)$ assets; $\mathrm{AT}_{\mathrm{it}-1}$ is firm i's beginning of the year $t$ total assets; $\Delta \mathrm{REV}_{\text {it }}$ is the difference in year $t$ and year $\mathrm{t}-1$ sales; $\Delta$ $\mathrm{AR}_{\mathrm{it}}$ is the difference between year $\mathrm{t}$ and year $\mathrm{t}-1$ trade account receivables; and $\mathrm{PPE}_{\text {it }}$ is net property plant and equipment both scaled by $\mathrm{AT}_{\mathrm{it}-1}$. Discretionary accruals are the difference between each firm's actual and predicted accruals, i.e.:

$$
\mathrm{DAC}_{\mathrm{it}}=\mathrm{TACit}-\left[\beta_{0}+\beta_{1}\left(1 / \mathrm{TA}_{\mathrm{it}-1}\right)+\beta_{2}\left(\Delta \mathrm{REV}_{\mathrm{it}}-\Delta \mathrm{AR}_{\mathrm{it}}\right) / \mathrm{TA}_{\mathrm{it}-1}+\beta_{3} \mathrm{PPE}_{\mathrm{it}}\right]
$$

In our models we include controls that may affect the cross sectional variability in the dependent variable, $\mathrm{DAC}_{\mathrm{it}}$.

\subsection{Control variables}

Relative to other companies, certain industries or firms may tend to generate higher accruals. In addition, it is natural that growth companies with increasing earnings and investments in working capital are more likely to produce greater accruals, and prior studies show that growth firms report higher accruals (McNichols, 2000). To control for the 
possibility that companies with greater total accruals may also have larger discretionary accruals that our accruals model does not capture, we include total accruals (ACRL $L_{i t}$ ) in our multivariate tests measured as the difference between firm i's year $t$ earnings before extraordinary items and net cash flow from operations scaled by beginning of year assets. Accruals studies typically control for size effects. Dechow and Dichev (2002) show that larger firms record larger accruals. Also, larger firms with larger investor following and more developed and sophisticated financial reporting systems may affect accrual levels (Becker et al., 1998; Reynolds and Francis, 2000). For each firm i we include the end of fiscal year t natural log of total assets (LnASSET ${ }_{i t}$ ). Reynolds and Francis (2000) provide evidence that the tendency to manage earnings increases with leverage. DeFond and Jiambalvo (1994) show that accruals are related to debt covenant breeches. In addition, debt may serve as a monitoring mechanism that constrains earnings management. To control for the effect that high debt levels may have on accruals, we include the variable $L^{2} V_{\text {it }}$ measured as firm i's end of year $\mathrm{t}$ long term debt scaled by $\mathrm{t}-1$ total assets.

Operating cash flows are a component of earnings and their levels correspond inversely with accruals. Further, the level of cash flow may affect the ability and/or need to use accruals, causing firms with higher (lower) operating cash flows to report lower (higher) discretionary accruals (Becker et al., 1998). We control for these effects by including operating cash flow deflated by the beginning of the year total assets $\left(\mathrm{OCF}_{\mathrm{it}}\right)$. Kothari et al. (2005) show that discretionary accruals are impacted by financial performance. Accordingly, we include $\mathrm{ROA}_{\mathrm{it}}$, income before extraordinary items divided by the beginning of the year total assets. Similar to our dependent variable, DAC ${ }_{\text {it }}$ (Houmes, 2013).

\subsection{Audit quality and highly valued equity}

We identify highly valued clients $\left(\mathrm{HV}_{\mathrm{it}-1}\right)$ as firms in the highest quintile of PEs (i.e. $\mathrm{P} / \mathrm{E}>28.07)$ and assign an indicator variable equal to 1 if the client is in this quintile of prior fiscal year end price-to-earnings ratios and 0 otherwise.

Our audit quality variables are as follows: big audit firm $\left(\mathrm{BIG}_{\mathrm{it}-1}\right)$, industry specialist audit firm $\left(\mathrm{SPEC}_{\mathrm{it}-1}\right)$, the audit-client tenure $\left(\mathrm{TEN}_{\mathrm{it}-1}\right)$ and an indicator variable if the auditor is both an industry specialist and has a long tenure auditor-client relationship (SPECTEN it-1 $_{1}$ ).

To investigate the relation between high valuations and the tendency of high audit quality auditors to mitigate accruals, we interact the audit quality variables with our highly valued equity dummy. Statistically significantly positive estimates for the audit quality, highly valued equity interaction terms: BIGN ${ }^{*} \mathrm{HV}_{\text {it-1 }}$, SPEC $* \mathrm{HV}_{\text {it-1 }}$, TEN ${ }^{*} \mathrm{HV}_{\text {it-1 }}$ and SPECTEN $* \mathrm{HV}_{\mathrm{it}-1}$, provide support for hypotheses that incentives associated with high valuations reduce the tendency of high quality audit firms to constrain accruals. Our models are as follows:

$$
\begin{gathered}
\left|\mathrm{DAC}_{\mathrm{it}}\right|=\alpha_{0}+\alpha_{1} \mathrm{ACRL}_{\mathrm{it}}+\alpha_{2} \mathrm{LnASSET}_{\mathrm{it}}+\alpha_{3} \mathrm{LEV}_{\mathrm{it}}+\alpha_{4} \mathrm{OCF}_{\mathrm{it}}+\alpha_{5} \mathrm{ROA}_{\mathrm{it}}+\alpha_{6} \mathrm{BIGN}_{\mathrm{it}-1}+ \\
\alpha_{7} \mathrm{HV}_{\mathrm{it}-1}+\alpha_{8} \mathrm{BIGN}^{*} \mathrm{HV}_{\mathrm{it}-1}+\varepsilon_{\mathrm{it}} \\
\left|\mathrm{DAC}_{\mathrm{it}}\right|=\alpha_{0}+\alpha_{1} \mathrm{ACRL}_{\mathrm{it}}+\alpha_{2} \mathrm{LnASSET}_{\mathrm{it}}+\alpha_{3} \mathrm{LEV}_{\mathrm{it}}+\alpha_{4} \mathrm{OCF}_{\mathrm{it}}+\alpha_{5} \mathrm{ROA}_{\mathrm{it}}+\alpha_{6} \mathrm{SPEC}_{\mathrm{it}-1}+ \\
\alpha_{7} \mathrm{HV}_{\mathrm{it}-1}+\alpha_{8} \mathrm{SPEC}^{*} \mathrm{HV}_{\mathrm{it}-1}+\varepsilon_{\mathrm{it}} \\
\left|\mathrm{DAC}_{\mathrm{it}}\right|=\alpha_{0}+\alpha_{1} \mathrm{ACRL}_{\mathrm{it}}+\alpha_{2} \mathrm{LnASSET}_{\mathrm{it}}+\alpha_{3} \mathrm{LEV}_{\mathrm{it}}+\alpha_{4} \mathrm{OCF}_{\mathrm{it}}+\alpha_{5} \mathrm{ROA}_{\mathrm{it}}+\alpha_{6} \mathrm{TEN}_{\mathrm{it}-1}+\alpha_{7} \mathrm{HV}_{\mathrm{it}-1} \\
+\alpha_{8} \mathrm{TEN} \mathrm{HV}_{\mathrm{it}-1}+\varepsilon_{\mathrm{it}}
\end{gathered}
$$




$$
\begin{gathered}
\left|\mathrm{DAC}_{\mathrm{it}}\right|=\alpha_{0}+\alpha_{1} \mathrm{ACRL}_{\mathrm{it}}+\alpha_{2} \mathrm{LnASSET}_{\mathrm{it}}+\alpha_{3} \mathrm{LEV}_{\mathrm{it}}+\alpha_{4} \mathrm{OCF}_{\mathrm{it}}+\alpha_{5} \mathrm{ROA}_{\mathrm{it}}+\alpha_{6} \mathrm{SPECTEN}_{\mathrm{it}-1}+ \\
\alpha_{7} \mathrm{HV}_{\mathrm{it}-1}+\alpha_{8} \operatorname{SPECTEN}^{*} \mathrm{HV}_{\mathrm{it}-1}+\varepsilon_{\mathrm{it}}
\end{gathered}
$$

\begin{tabular}{|c|c|}
\hline Variables & definition \\
\hline$\left|\mathrm{DAC}_{\mathrm{it}}\right|$ & Firm i's fiscal year $t$ absolute value of discretionary accruals \\
\hline $\mathrm{ACRL}_{\text {it }}$ & Firm i's fiscal year $\mathrm{t}$ total accruals \\
\hline LnASSET $_{\text {it }}$ & Firm i's fiscal year $t$ natural log of total assets \\
\hline $\mathrm{LEV}_{\mathrm{it}}$ & Firm i's fiscal year $t$ long term debt divided by fiscal year $t-1$ total assets \\
\hline $\mathrm{OCF}_{\text {it }}$ & $\begin{array}{l}\text { Firm i's fiscal year t cash flow from operating activates divided by fiscal year t-1 } \\
\text { total assets }\end{array}$ \\
\hline $\mathrm{ROA}_{\mathrm{it}}$ & $\begin{array}{l}\text { Firm i's fiscal year t income before extraordinary items divided by fiscal year t-1 } \\
\text { total assets }\end{array}$ \\
\hline $\mathrm{HV}_{\mathrm{it}-1}$ & $\begin{array}{c}\text { An indicator variable equal to } 1 \text { for firms in the highest quintile of fiscal year t-1 } \\
\text { price-to-earnings ratios }\end{array}$ \\
\hline$A Q_{\text {it-1 }}$ & Four measures of audit quality defined as follows \\
\hline $\mathrm{BIG}_{\mathrm{it}-1}$ & $\begin{array}{c}\text { An indicator variable equal to } 1 \text { if at the end of fiscal year t-1 the auditor is } \\
\text { Auditing Organization of Iran }\end{array}$ \\
\hline $\mathrm{SPEC}_{\mathrm{it}-1}$ & $\begin{array}{c}\text { An indicator variable equal to } 1 \text { if at the end of fiscal year t-1 the auditor is an } \\
\text { industry specialist }\end{array}$ \\
\hline $\mathrm{TEN}_{\mathrm{it}-1}$ & $\begin{array}{c}\text { An indicator variable equal to } 1 \text { if at the end of fiscal year t-1 the auditor tenure is } \\
\text { greater than or equal to four years }\end{array}$ \\
\hline SPECTEN $_{\mathrm{it}-1}$ & $\begin{array}{l}\text { An indicator variable equal to } 1 \text { if at the end of fiscal year t-1 the auditor is an } \\
\text { industry specialist and tenure is greater than or equal to five years }\end{array}$ \\
\hline $\mathrm{BIG} * \mathrm{HV}_{\mathrm{it}-1}$ & An interaction term between BIGNit-1 and HVit-1 \\
\hline SPEC $* \mathrm{HV}_{\mathrm{it}-1}$ & An interaction term between SPECit-1 and HVit-1 \\
\hline TEN *HV $\mathrm{Ht}_{\mathrm{i}-1}$ & An interaction term between TENit-1 and HVit-1 \\
\hline SPECTEN $* \mathrm{HV}_{\mathrm{it}-1}$ & An interaction term between SPECTENit-1 and HVit-1 \\
\hline
\end{tabular}

Table 1. Variable definitions.

\section{RESULTS}

\subsection{Descriptive statistics}

Descriptive statistics of the main research variables are presented in Table (2). As can be seen, the average absolute value of discretionary accruals (|DACC $\mid$ ) is equal to 0.14 and suggests that the studied companies on average have $14 \%$ of the discretionary accruals which its range is between 0 and 2.22. The average of financial leverage (LEV) is equal to 0.10 and indicates that on average $10 \%$ of the required funds of studied companies are provided from the debt. Also, the average of return on assets (ROA) indicates that on average $16 \%$ of the net profits of companies are acquired from applying corporate assets. The average of big audit organization (BIG) is equal to 0.22 which shows that $22 \%$ of the financial statements of studied companies have been investigated by large audit firms (Iran Audit Organization). The average of industry specialist auditor (SPEC) is equal to 0.42 which shows that $42 \%$ of the financial statements of studied companies have been investigated by industry specialist auditors. The average of auditor tenure (TEN) is equal to 0.53 suggesting that $53 \%$ of the companies were investigated by the same auditor for 4 years. The results also show that $31 \%$ of the observations involve specialist and long tenure audit client and $20 \%$ have over-valued equity. 
Table 2. Descriptive statistics.

\begin{tabular}{|c|c|c|c|c|c|}
\hline Variables & Mean & Median & Maximum & Minimum & Std. Dev. \\
\hline $\mid$ DACit & 0.14 & 0.1 & 2.22 & 0 & 0.18 \\
\hline ACRL $_{\text {it }}$ & 0.11 & 0.08 & 1.08 & 0 & 0.11 \\
\hline LnASSET $_{\text {it }}$ & 13.45 & 13.26 & 18.55 & 10.03 & 1.46 \\
\hline LEV $_{\text {it }}$ & 0.10 & 0.06 & 1.56 & 0 & 0.13 \\
\hline OCF $_{\text {it }}$ & 0.14 & 0.11 & 1.12 & -0.50 & 0.16 \\
\hline ROA $_{\text {it }}$ & 0.16 & 0.11 & 2.82 & -0.37 & 0.27 \\
\hline BIG $_{\text {it }}$ & 0.22 & 0 & 1 & 0 & 0.41 \\
\hline SPEC $_{\text {it }}$ & 0.42 & 1 & 1 & 0 & 0.45 \\
\hline TEN $_{\text {it }}$ & 0.53 & 0 & 1 & 0 & 0.50 \\
\hline SPECTEN $_{\text {it }}$ & 0.31 & 0 & 1 & 0 & 0.42 \\
\hline HV $_{\text {it }}$ & 0.20 & 0 & 1 & 0 & 0.40 \\
\hline
\end{tabular}

\subsection{Correlations}

Table 3 provides correlations. Correlations in Table 3 reveal that size, leverage and operating are inversely related to discretionary and total accruals, cash flow and ROA are positively related to total absolute value of discretionary accruals. All control variables except for size are also positively correlated with our $\mathrm{HV}_{\text {it-1 }}$ indicator variable. While coefficients are negative between each of our audit quality variables and HVit-1.

Table 3. Correlations.

\begin{tabular}{|c|c|c|c|c|c|c|c|c|c|c|c|}
\hline & DA & ACRL & ASSET & LEVIT & OCFIT & ROA & BIG & SPE & TEN & SPETEN & HV \\
\hline DA & 1 & 0.26 & -0.03 & -0.03 & 0.14 & 0.60 & -0.03 & -0.10 & -0.01 & -0.002 & 0.06 \\
\hline ACRL & 0.26 & 1 & 0.04 & -0.04 & -0.06 & 0.11 & 0.03 & 0.03 & 0.02 & 0.18 & 0.03 \\
\hline ASSET & -0.03 & 0.04 & 1 & 0.00 & 0.09 & 0.04 & 0.20 & 0.30 & 0.08 & 0.08 & -0.05 \\
\hline LEVIT & -0.03 & -0.04 & 0.00 & 1 & -0.06 & -0.13 & -0.06 & 0.04 & -0.06 & -0.06 & 0.02 \\
\hline OCFIT & 0.14 & -0.06 & 0.09 & -0.06 & 1 & 0.47 & 0.05 & 0.05 & 0.03 & -0.05 & 0.00 \\
\hline ROA & 0.60 & 0.11 & 0.04 & -0.13 & 0.47 & 1 & 0.04 & 0.01 & -0.01 & 0.12 & 0.03 \\
\hline BIG & -0.03 & 0.03 & 0.20 & -0.06 & 0.05 & 0.04 & 1 & 0.23 & 0.37 & 0.26 & -0.07 \\
\hline SPE & -0.10 & 0.03 & 0.30 & 0.04 & 0.05 & 0.01 & 0.23 & 1 & 0.20 & 0.14 & -0.02 \\
\hline TEN & -0.01 & 0.02 & 0.08 & -0.06 & 0.03 & -0.01 & 0.37 & 0.20 & 1 & 0.57 & -0.09 \\
\hline SPETEN & -0.002 & 0.18 & 0.08 & -0.06 & -0.05 & 0.12 & 0.26 & 0.14 & 0.57 & 1 & -0.07 \\
\hline HV & 0.06 & 0.03 & -0.05 & 0.02 & 0.00 & 0.03 & -0.07 & -0.02 & -0.09 & -0.07 & 1 \\
\hline
\end{tabular}

\subsection{F-Limer \& Huasman test}

To determine the appropriate method for estimating the model, first F-Limer test is performed to determine whether the data are pool or panel, also Hausman test is performed to select one of the fixed effects and random effects methods. As can be seen from the results of Table (4), P-value of F-Limer test is equal to 0.000 and is less than $1 \%$ error level. Thus, the data are panel. Consequently, the Hausman test is performed to select one of the fixed effects 
and random effects methods. As can be seen from the results of Table (5), P-value of Hausman test is equal to 0.000 and is less than $5 \%$ error level. Thus, the results show that the fixed effects method is most appropriate method for estimating regression model of research.

Table 4. F-limer test.

\begin{tabular}{|c|c|c|c|}
\hline Model & Statistic & Prob. & Test result \\
\hline $\mathrm{H}_{1}$ (BIG) & 4.46 & 0.00000 & Panel data \\
\hline $\mathrm{H}_{2}$ (SPEC) & 4.37 & 0.00000 & Panel data \\
\hline $\mathrm{H}_{3}$ (TEN) & 4.43 & 0.00000 & Panel data \\
\hline $\mathrm{H}_{4} \quad$ (SPECTEN) & 4.41 & 0.00000 & Panel data \\
\hline
\end{tabular}

Table 5. Hausman test.

\begin{tabular}{|c|c|c|c|}
\hline Model & Statistic & Prob. & Test result \\
\hline $\mathrm{H}_{1}$ (BIG) & 65.65 & 0.00000 & Fixed effects method \\
\hline $\mathrm{H}_{2}$ (SPEC) & 66.53 & 0.00000 & Fixed effects method \\
\hline $\mathrm{H}_{3}$ (TEN) & 64.98 & 0.00000 & Fixed effects method \\
\hline $\mathrm{H}_{4}$ (SPECTEN) & 65.04 & 0.00000 & Fixed effects method \\
\hline
\end{tabular}

\subsection{The regression results}

Table 6 shows results of main tests for our income increasing discretionary accruals sample for models depicted in equations. Adjusted $\mathrm{R}^{2}$ exceeds 70 percent, indicating that explanatory variables of model explain more than 70 percent of changes in the earnings management (the dependent variable). The F-statistic values are more than 10 and its Pvalues are 0.000 , indicating that the models are significant in general. Also, Durbin-Watson statistic values are all between 1.5 and 2.5 stating that there is no autocorrelation problem between research variables. Total accrual $\left(A C R L_{i t}\right)$ is significant and positive. As expected and in accordance with prior accruals studies, estimates for assets and operating cash flow are negative, suggesting that greater firm size and operating cash flow enhance accruals quality. The coefficients for $\mathrm{ROA}_{i t}$ are positive. Discretionary accruals increase with (scaled) income. $\mathrm{HV}_{\text {it-1 }}$ is positive. The coefficients for the Big, specialist, and long tenure-specialist audit quality measures are negative. However, the estimate for our audit quality variable, TEN $\mathrm{it}_{\mathrm{i}}$, is insignificant. We test hypotheses with interaction terms between our highly valued equity and audit quality variables: BIGN ${ }^{*} \mathrm{HV}_{\mathrm{it}-1}$, SPEC $* \mathrm{HV}_{\mathrm{it}-1}$, TEN $* \mathrm{HV}_{\mathrm{it}-1}$ and SPECTEN $* \mathrm{HV}_{\mathrm{it}-1}$. For each of the four alternative audit quality measures, discretionary accruals increase when the client firm is highly valued.

Table 6. Regression results.

\begin{tabular}{|c|c|c|c|c|}
\hline & $\begin{array}{c}\text { BIG } \\
\text { coefficient } \\
(\mathrm{p} \text {-value })\end{array}$ & $\begin{array}{c}\text { SPEC } \\
\text { coefficient } \\
(\mathrm{p} \text {-value })\end{array}$ & $\begin{array}{c}\text { TEN } \\
\text { coefficient } \\
(\mathrm{p} \text {-value })\end{array}$ & $\begin{array}{c}\text { SPECTEN } \\
\text { coefficient } \\
(\mathrm{p} \text {-value })\end{array}$ \\
\hline $\mathrm{ACRL}_{\text {it }}$ & $0.297(0.000)$ & $0.270(0.000)$ & $0.295(0.000)$ & $0.324(0.000)$ \\
\hline LnASSET $_{\text {it }}$ & $-0.005(0.053)$ & $-0.027(0.055)$ & $-0.006(0.042)$ & $-0.005(0.086)$ \\
\hline $\mathrm{LEV}_{\text {it }}$ & $0.076(0.035)$ & $0.088(0.0142)$ & $0.081(0.024)$ & $0.075(0.035)$ \\
\hline $\mathrm{OCF}_{\text {it }}$ & $-0.186(0.000)$ & $-0.183(0.000)$ & $-0.188(0.000)$ & $-0.204(0.000)$ \\
\hline $\mathrm{ROA}_{\text {it }}$ & $0.453(0.000)$ & $0.452(0.000)$ & $0.453(0.000)$ & $0.465(0.000)$ \\
\hline
\end{tabular}




\begin{tabular}{|c|c|c|c|c|}
\hline $\mathrm{HV}_{\text {it }}$ & $0.008(0.085)$ & $0.026(0.094)$ & $0.011(0.084)$ & $0.009(0.063)$ \\
\hline $\mathrm{BIG}_{\mathrm{it}}$ & $-0.023(0.050)$ & & & \\
\hline $\mathrm{BIG} * \mathrm{HV}_{\mathrm{it}-1}$ & $0.027(0.070)$ & & & \\
\hline $\mathrm{SPEC}_{\mathrm{it}}$ & & $-0.035(0.001)$ & & \\
\hline $\mathrm{SPEC} * \mathrm{HV}_{\mathrm{it}-1}$ & & $-0.017(0.054)$ & & \\
\hline $\mathrm{TEN}_{\mathrm{it}}$ & & & $-0.001(0.467)$ & \\
\hline TEN $* \mathrm{HV}_{\mathrm{it}-1}$ & & & $0.007(0.07)$ & \\
\hline SPECTEN $_{\text {it }}$ & & & & $-0.052(0.000)$ \\
\hline $\begin{array}{c}\text { SPECTEN * } \\
\text { HV }_{\text {it- } 1}\end{array}$ & & & & $0.009(0.045)$ \\
\hline Adjusted $\mathrm{R}^{2}$ & 0.732 & 0.733 & 0.731 & 0.736 \\
\hline F-statistic & 10.458 & 10.48 & 10.37 & 10.65 \\
\hline Prob(F-statistic) & 0.000 & 0.000 & 0.000 & 0.000 \\
\hline Durbin-Watson & 1.99 & 2.00 & 1.99 & 2.01 \\
\hline
\end{tabular}

\section{DISCUSSION OF RESULTS AND CONCLUSION}

In this study we examined the accruals decreasing effect of high quality auditors on highly valued audit clients. For achieving this aim, the discretionary accruals as criteria for earning management was determined by using the modified-Jones model and audit firm size, auditor industry specialization and auditor tenure were used as audit quality variable. Also overvalued equity variable was used as an independent variable and an indicator with audit quality variables. The results show that management incentives associated with highly valued equity reduce the tendency of high quality auditors to reduce accruals. In specific, a negative relationship was shown between audit quality variable and absolute discretionary accruals which all were significant except for auditor tenure, suggesting that absolute discretionary accruals decrease when audit quality is high but the negative relationship is inversed or reduced when the company's equity is overvalued. The only audit quality variable which keeps its negative effect is auditor industry specialization suggesting that this variable is the most effective audit quality variable. Also, the test results of control variables of research indicate that there is significant and positive relationship between the variables of total accrual, financial leverage (LEV) and return on assets (ROA), with earnings management and a significant negative relationship between the variables of firm size (LnASSET) and cash flow with discretionary accruals.

\section{References}

[1] Antle R., Nalebuff B., Journal of Accounting Research 29 (1991) 31-54.

[2] Anderson K., Brooks C., Journal of Business Finance \& Accounting 7 (2006) 10631086.

[3] Azibi J., Rajhi M. T. Auditor's Choice and Earning Management after Enron Scandals: Empirical Approach in French Context. The Business \& Economics (EABR) and Teaching \& Education (TLC) Conferences, Rothenburg, Germany (2008).

[4] Abdul Rahman R., Ali F. H. M., Managerial Auditing Journal 21(7) (2006) 783-804.

[5] Becker C. L., Defond M. L., Jiambalvo J., Subramanyam K. R., Contemporary Accounting Research 15 (1998) 1-24. 
[6] Beatty R., The Accounting Review 4 (1989) 693-709.

[7] Carcello J. V., Nagy A. L., Auditing: A Journal of Practice \& Theory 23 (2004) 55-69.

[8] Chen J. Earning management and the performance of seasoned equity offerings: A new looks based on agency costs of overvalued equity (2007). Available:https://server1.tepper.cmu.edu/gsiadoc/WP/2007-E38.pdf

[9] Chi J. D., Gupta M., Journal of Banking \& Finance 33 (2009) 1652-1663.

[10] Chen K. Y., Lin K. L., Zhou J., Managerial Auditing Journal 20(1) (2005) 86-104.

[11] DeAngelo L. E., Journal of Accounting and Economics 3(2) (1981) 113-127

[12] Davis L. R., Soo B., Trompeter G,. Auditor Tenure, Auditor Independence and Earnings Management. Working Paper, Boston College, Boston, MA, (2000).

[13] Houmes R., Skantz T., Journal of Business Finance \& Accounting 37 (2010) 60-92.

[14] Houmes R., Dickins D., O’Keefe R., Advances in Accounting 28 (2012) 235-242.

[15] Houmes Robert, Foley Maggie, Cebula Richard., Accounting Research Journal 26(1) (2013) 56-74.

[16] Jensen M., Financial Management 34 (2005) 5-20.

[17] Memis M. U., Cetenak E. H., International Journal of Economics and Financial Issues 2(4) (2012) 460-469.

[18] Mansi S. A., Maxwell W. F., Miler D. P., Journal of Accounting Research 42 (2004) 755-793.

[19] Renas S. M., Cebula R. J., American Journal of Economics and Sociology 64 (2005) 743-756.

[20] Zgarni I., Hlioui K., Zehri F., International Journal of Accounting and Financial Reporting 2(2) (2012) 17-33. 